\title{
Pancreatic Effects of Diesel Exhaust Particles in Mice with Type 1 Diabetes Mellitus
}

\author{
Abderrahim Nemmara Suhail Al-Salam ${ }^{b}$ Sumaya Beegam ${ }^{a}$ Priya Yuvaraju \\ Javed Yasinc Badreldin H. Alid
}

Departments of aPhysiology, ${ }^{b}$ Pathology and 'Internal Medicine, College of Medicine and Health Sciences, United Arab Emirates University, Al Ain, United Arab Emirates; 'Department of Pharmacology and Clinical Pharmacy, College of Medicine \& Health Sciences, Sultan Qaboos University, Al-Khod, Sultanate of Oman

\section{Key Words}

Particulate air pollution $\bullet$ Diesel exhaust particles $\bullet$ Pancreas $\bullet$ Oxidative stress $\bullet$ Streptozotocin - Type I diabetes $•$ Mice

\begin{abstract}
Background/Aims: Epidemiologically, diabetics are more prone to the adverse health effects of particulate air pollution than healthy individuals. We recently demonstrated an increased cardiovascular and respiratory susceptibility to diesel exhaust particles (DEP) in mice with type 1 diabetes. However, the pancreatic effects of DEP in healthy and diabetic mice are unknown. Methods: Presently, we evaluated the pancreatic impact of DEP in healthy mice, and mice with streptozotocin-induced type 1 diabetes. Four weeks following induction of diabetes, mice were intratracheally instilled (i.t.) with either DEP $(0.4 \mathrm{mg} / \mathrm{kg})$ or saline, and several histological and biochemical endpoints were measured $24 \mathrm{~h}$ thereafter. Results: Neither the histology nor the stain for apoptosis in the pancreatic islets and exocrine glands were affected by DEP. In diabetic mice exposed to saline, the islet cells showed cellular vacuolation and apoptotic islet cells $(71.6 \pm 2.6 \%)$. In diabetic mice exposed to DEP, a more marked decrease in the size and number of islet cells with cellular vacuolation along with a significant increase of apoptotic islet cells $(79.1 \pm 1.7 \%, P<0.05)$ were observed. In diabetic mice, DEP increased significantly pancreatic amylase activity and markers of oxidative stress including 8-isoprostane, superoxide dismutase and reduced glutathione compared with either diabetic mice exposed to saline or non-diabetic mice exposed to DEP. Staining for inducible nitric oxide synthase (iNOS) in healthy mice exposed to either saline or DEP showed no staining in either pancreatic islets cells or acini. In saline-treated diabetic mice, a mild cytoplasmic staining for iNOS in some pancreatic islet cells was observed. Notably, in diabetic mice exposed to DEP, a marked cytoplasmic staining for iNOS in most pancreatic islet cells and some acinar cells was seen. Conclusion: We conclude that DEP caused detrimental effects on the pancreas of diabetic mice, and that oxidative stress is responsible, at least partially, for the observed effects.
\end{abstract}

Copyright (C) 2014 S. Karger AG, Base 


\section{Cellular Physiology and Biochemistry}

Cell Physiol Biochem 2014;33:413-422

DOI: $10.1159 / 000356680$

Published online: February 11, 2014

S. Karger AG, Basel

www.karger.com/cpb

Nemmar et al.: Diabetes and Pancreatic Effects of Diesel Particles

\section{Introduction}

Exposure to particulate air pollution has been linked with increased pulmonary and extrapulmonary mortality and morbidity [1]. The World Health Organization estimated that the mass of fine particles $<2.5 \mu \mathrm{m}$ in aerodynamic diameter $\left(\mathrm{PM}_{2.5}\right)$ contributed to $\approx 800,000$ premature deaths per year, ranking $\mathrm{PM}_{2.5}$ as the 13th leading cause of worldwide mortality [2].

Diesel exhaust particles (DEP), the main component of $\mathrm{PM}_{2.5}$ and ultrafine (nano) particles (diameter $\leq 0.1 \mu \mathrm{m}$ ) in urban areas, are a significant contributor to inhaled particulate matter pollution [3]. These ultrafine particles have high alveolar deposition and ability to translocate to the bloodstream [3]. Acute exposure to DEP in healthy human volunteers caused pulmonary and extrapulmonary effects [4].

Particulate air pollution influences vulnerability to adverse events and may be detrimental to high-risk groups such as diabetic patients [5-8]. It has been reported that among diabetics, the risk of hospital admissions for heart diseases is 2 -fold greater than that for non-diabetic people [9]. To verify and explain these observations, several experimental studies have been performed to test whether and to what extent the effects of particulate air pollution are aggravated in animal models of type 1 and type 2 diabetes [10-14].

We have recently demonstrated an increase in respiratory, systemic and coagulation susceptibility in mice with type 1 diabetes acutely exposed to DEP $[12,13]$. However, the possible effects of DEP on the pancreas in healthy mice and those with type 1 diabetes have, as far as we are aware, not been investigated so far.

The hypothesis tested here is whether and to what extent can DEP exert injurious effects on the pancreas in type 1 diabetic mice. Consequently, the goal of this study is to evaluate the pancreatic effects of DEP in healthy mice, and mice with streptozotocin (STZ)induced type 1 diabetes by measuring several histological and biochemical endpoints $24 \mathrm{~h}$ post-DEP exposure.

\section{Material and Methods}

\section{Diesel exhaust particles (DEP)}

The DEP (SRM 2975) were obtained from the National Institute of Standards and Technology (NIST, Gaithersburg, MD, USA), and were suspended in sterile saline ( $\mathrm{NaCl} 0.9 \%$ ) containing Tween 80 (0.01\%). To minimize aggregation, particle suspensions were always sonicated (Clifton Ultrasonic Bath, Clifton, New Jersey, USA) for $15 \mathrm{~min}$ and vortexed before their dilution and prior to intratracheal (i.t.) administration. Control animals received saline containing Tween 80 (0.01\%).

These particles were previously analysed by transmission electron microscopy, and shown to have a substantial amount of ultrafine (nano) sized particle aggregates, and larger particle aggregates $[15,16]$.

\section{Animals and treatments}

This project was reviewed and approved by the Institutional Review Board of the United Arab Emirates University, College of Medicine and Health Sciences, and experiments were performed in accordance with protocols approved by the Institutional Animal Care and Research Advisory Committee.

Male TO mice (HsdOla:TO, Harlan, UK) were housed in light (12-h light:12-h dark cycle) and temperature-controlled $\left(22 \pm 1^{\circ} \mathrm{C}\right)$ rooms. They had free access to commercial laboratory chow and were provided tap water ad libitum.

Type 1 diabetes mellitus was induced in male TO mice (6 to 8 weeks old) by intraperitoneal (i.p.) injection of $200 \mathrm{mg} / \mathrm{kg}$ body weight of STZ (Sigma Chemical, St. Louis, MO) [12, 13, 17, 18]. Tail vein blood glucose samples were measured before and during 4 weeks after injection to ensure induction of diabetes. The nondiabetic (control) mice were injected i.p. with the vehicle $(0.1 \mathrm{~mol} / \mathrm{l}$ citrate buffer, $\mathrm{pH} 4.5)$. Fourweeks post-STZ injection, mice were anesthetized with sodium pentobarbital (60 mg/kg, i.p.), and placed supine with extended neck on an angled board. A Becton Dickinson 24 Gauge cannula was inserted via the mouth into the trachea. Either the DEP suspensions $(0.4 \mathrm{mg} / \mathrm{kg})$ or saline-only were instilled intratrachealy 


\section{Cellular Physiology and Biochemistry}

Cell Physiol Biochem 2014;33:413-422

DOI: $10.1159 / 000356680$

Published online: February 11, 2014

C) 2014 S. Karger AG, Basel

www.karger.com/cpb

(i.t.) $(50 \mu \mathrm{l})$ via a sterile syringe and followed by an air bolus of $50 \mu \mathrm{l}$ to diabetic and non-diabetic mice.

\section{Measurement of pancreatic enzymes and markers of oxidative stress}

After the exposure to either DEP or saline, animals were sacrificed by an overdose of sodium pentobarbital, and their pancreases were quickly collected and rinsed with ice-cold PBS (pH 7.4) before homogenization in $0.1 \mathrm{M}$ phosphate buffer, $\mathrm{pH} 7.4$, containing $0.15 \mathrm{M} \mathrm{KCl}, 0.1 \mathrm{mM}$ EDTA, $1 \mathrm{mM}$ DTT and $0.1 \mathrm{mM}$ phenylmethylsulfonylfluoride at $4^{\circ} \mathrm{C}$. The homogenates were centrifuged for $10 \mathrm{~min}$ at $3000 \mathrm{x} g$ to remove cellular debris and supernatants were used for further analysis. Protein content was measured by Bradford's method, as described before $[19,20]$.

The activities of amylase and lipase were measured using colorimetric assays (Roche Diagnostics, Indianapolis, USA).

The concentrations of 8-isoprostane were determined using an ELISA Kit (Cayman Chemicals, Michigan, USA). The concentration of reduced glutathione (GSH) and the activity of superoxide dismutase (SOD) were determined using colorimetric assay kits (Cayman Chemicals, Michigan, USA).

\section{Histology}

Light microscopy : pancreas was excised, washed with ice-cold saline, blotted with filter paper and weighed. Each pancreas was cassetted and fixed directly in $10 \%$ neutral formalin for 24 hours, which was followed by dehydration in increasing concentrations of ethanol, clearing with xylene and embedding with paraffin. Five- $\mu \mathrm{m}$ sections were prepared from paraffin blocks and stained with haematoxylin and eosin. The stained sections were evaluated blindly using light microscopy by the histopathologist who participated in this project.

Staining for apoptosis : this was performed using a signal stain cleaved caspase-3 Immunohistochemical detection kit (Cell Signaling Technology, Boston, USA). This kit was used to detect the activation of caspase-3 using the avidin- biotin immunoperoxidase method to detect intracellular cleaved caspase-3 protein. Staining was performed on $5 \mu \mathrm{m}$ paraffin sections from the pancreas by a standard technique using rabbit anti-cleaved caspase 3 (clone Asp175, 1:50) [21]. Known positive control sections for apoptosis were used. For the negative control, primary antibody was replaced with normal rabbit serum.

Staining for inducible nitric oxide synthase (iNOS): five-micrometer sections were prepared and mounted on aminopropyltriethoxysilane (APES) coated slides. After dewaxing with xylene and rehydrating with graded alcohol, slides were placed in a $0.01 \mathrm{M}$ citrate buffer solution $(\mathrm{pH}=6.0)$, and pretreatment procedures to unmask the antigens were performed in a microwave oven for 10 minutes. After that, sections were treated with peroxidase block for 20 minutes followed by protein block for 10 minutes. Then, the sections were stained using the streptavidin-biotin immunohistochemical method for induced nitric oxide synthase (iNOS).

Anti- iNOS (Thermo Scientific, USA, 1:200 rabbit polyclonal) was applied on sections overnight at $4^{\circ} \mathrm{C}$, followed by washing the sections in phosphate buffer saline (PBS) for 15 minutes in three changes, then EnVision-FLEX-HRP (DAKO Cytomation, Denmark) was added for 20 minutes at room temperature, which was followed by washing in PBS for 15 minutes and addition of 3,3' diaminobenzidine chromogen for 5 minutes ; this was followed by washing in PBS and counter staining with haematoxylin. Then the sections were dehydrated, cleared and mounted in DPX. An appropriate positive control was used. For negative control, the primary antibody was replaced by phosphate buffer and carried for the whole procedure.

Interpretation of pancreatic sections : apoptotic cells were counted in pancreatic islets in all sections in each group using Image J software (http://rsbweb.nih.gov/ij/). Apoptotic cells are defined by the presence of cytoplasmic brown granular staining. The percentage of apoptotic cells in relation to the total number of cells in each pancreatic islet was determined for the different groups. Positive cells for iNOS were defined by cytoplasmic brown granular staining.

\section{Statistics}

Data were expressed as means \pm SEM, and were analyzed with GraphPad Prism Version 4.01 for Windows software (Graphpad Software Inc., San Diego, USA). For blood glucose concentrations and body weight change, comparisons were performed using unpaired Student's t-test. For all the other measured parameters, comparisons between groups were performed by analysis of variance (ANOVA), followed by Newman-Keuls multiple-range tests. $P$ values $<0.05$ are considered significant. 
Fig. 1. Characteristics of study animals. Body weight (A) and blood glucose concentrations (B). Data are mean \pm SEM $(n=24)$.

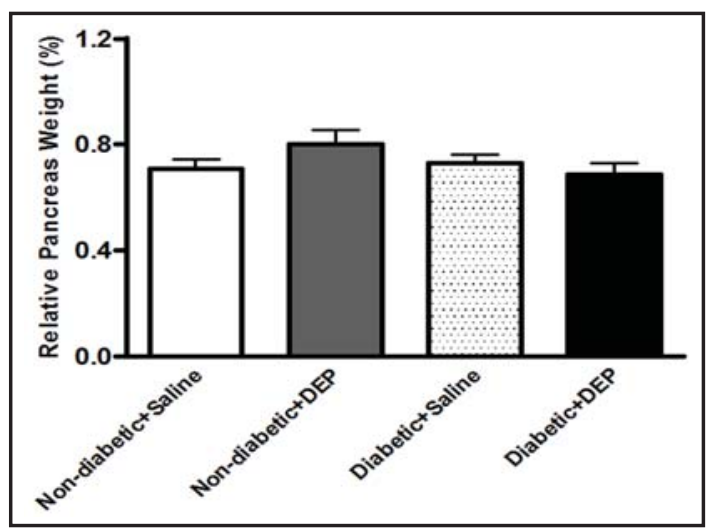

Fig. 2. Relative pancreas weight, $24 \mathrm{~h}$ after intratracheal instillation of either saline or diesel exhaust particles (DEP, $0.4 \mathrm{mg} / \mathrm{kg}$ ) in either nondiabetic or diabetic mice. Data are mean \pm SEM $(n=6)$.

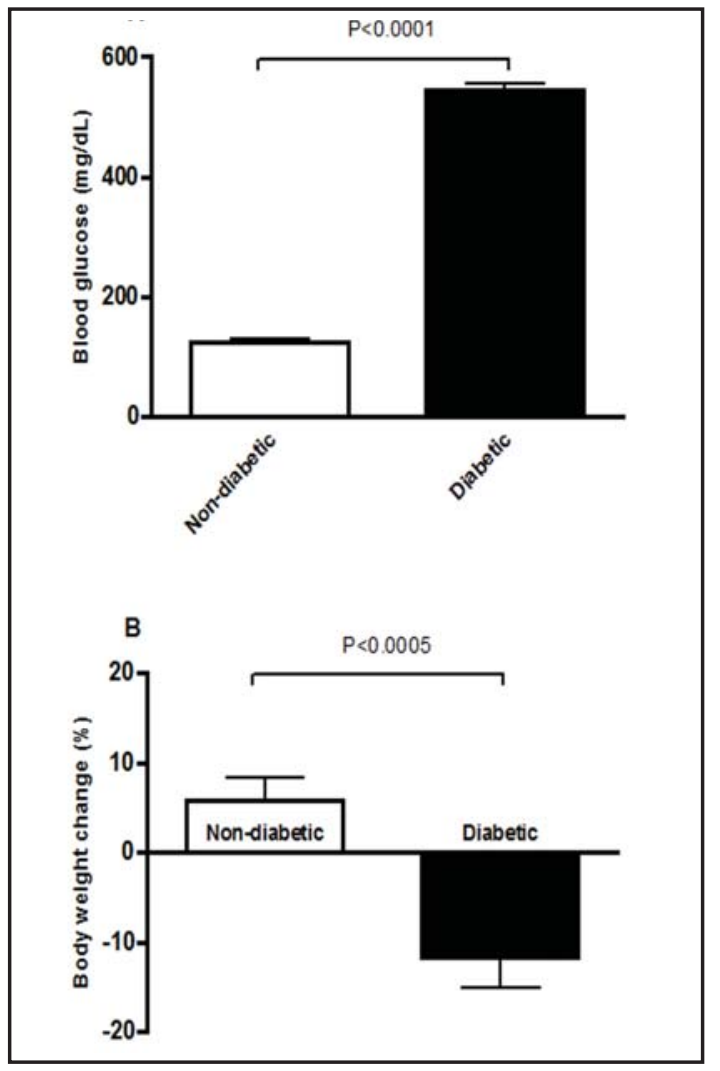

\section{Results}

General characteristics of the diabetic and non-diabetic mice

The mean blood glucose concentration was significantly $(P<0.0001)$ increased in diabetic mice compared with that of nondiabetic mice (Fig. 1A).

The mean body weight of diabetic mice was significantly $(P<0.0005)$ decreased compared with nondiabetic mice (Fig. 1B).

Effect of DEP on relative pancreatic weight in diabetic and non-diabetic mice

Figure 2 shows that the pancreatic weight relative to body weight was not significantly affected by DEP in either diabetic or non-diabetic mice.

Effect of DEP on pancreatic histology and apoptosis in diabetic and non-diabetic mice

Figure 3 shows representative micrographs of pancreas from the four studied groups. Pancreas obtained from non-diabetic mice exposed to saline showed normal architecture and histology of pancreatic islets and exocrine glands (Fig. 3A). In the last group, the stain for apoptosis showed no evidence of apoptotic cells in the examined sections (Fig. 3B). In the non-diabetic group exposed to DEP, the pancreas showed normal architecture and histology of pancreatic islets and exocrine glands (figure 3C). In the last group, the stain for apoptosis showed no evidence of apoptotic cells in the examined sections (Fig. 3D). The pancreas obtained from diabetic mice treated with saline displayed normal architecture and histology of pancreatic exocrine glands. The islet cells show cellular vacuolation and irregularity in morphology (Fig. 3E). In the last group, the stain for apoptosis showed apoptotic islet cells in the examined sections (Fig. 3F). The pancreas of diabetic mice exposed to DEP presented normal architecture and histology of pancreatic exocrine glands. The islet cells displayed marked decrease in size and number with cellular vacuolation and irregularity in 


\section{Cellular Physiology and Biochemistry}

Cell Physiol Biochem 2014;33:413-422

DOI: $10.1159 / 000356680$

Published online: February 11, 2014

Fig. 3. Cleaved caspase 3 in pancreatic tissue $24 \mathrm{~h}$ after intratracheal instillation of either saline or diesel exhaust particles $(0.4 \mathrm{mg} / \mathrm{kg})$ in either non-diabetic or diabetic mice. A: the saline-treated nondiabetic group shows normal architecture and histology of pancreatic islets (thick arrow) and exocrine glands, H\&E. B: in the saline-treated non-diabetic group, the stain for apoptosis shows no evidence of apoptotic cells in the examined sections (thick arrow) using the streptavidin-biotin immunoperoxidase method. C: the DEPtreated non-diabetic group shows normal architecture and histology of pancreatic islets (thick arrow) and exocrine glands, H\&E. D: in the DEP-treated non-diabetic group, the stain for apoptosis shows no evidence of apoptotic cells in the examined sections (thick arrow), streptavidin-biotin immunoperoxidase method. E: the salinetreated diabetic group shows normal architecture and histology of pancreatic exocrine glands. The islet cells (thick arrow) show cellular vacuolation and irregularity in morphology, H\&E. F: in the saline-treated diabetic group, the stain for apoptosis shows apoptotic islet cells in the exam-

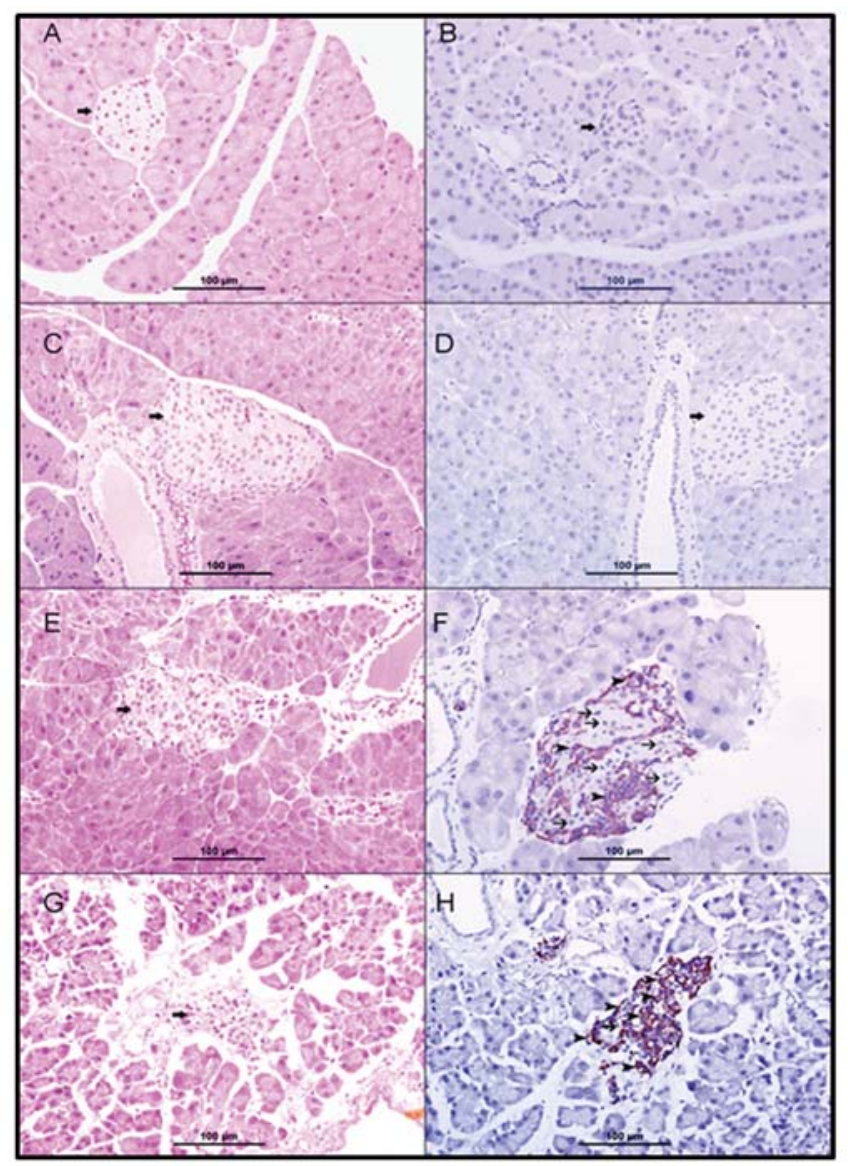
ined sections (arrow head) and normal cells (thin arrow) using the streptavidin-biotin immunoperoxidase method. G: the DEP-treated diabetic group shows normal architecture and histology of pancreatic exocrine glands. The islet cells (thick arrow) analysis shows a marked decrease in their numbers with cellular vacuolation and irregularity in morphology, H\&E. H: in the DEP-treated diabetic group, the stain for apoptosis shows many apoptotic islet cells (arrow head) and few normal cells (thin arrow) using the streptavidinbiotin immunoperoxidase method.

morphology (Fig. 3G). In the last group, the stain for apoptosis showed many apoptotic islet cells in the examined sections involving almost all the islet (Fig. $3 \mathrm{H}$ ).

Figure 4 shows no evidence for apoptotic cells in non-diabetic mice exposed to either saline or DEP. In saline-treated diabetic mice, about $72 \%$ of islet cells were apoptotic when examining 800 islet cells, and $28 \%$ of them did not show any staining for apoptosis. In diabetic mice exposed to DEP, the number of apoptotic islet cells increased significantly $(P<0.05)$ compared with the diabetic+saline group. When examining 800 islet cells, about $79 \%$ were apoptotic and $21 \%$ showed no staining for apoptosis.

\section{Effect of DEP on the activity of pancreatic amylase and lipase in diabetic and non-diabetic} mice

In non-diabetic mice, DEP exposure induced a significant increase in the activity of pancreatic amylase compared with the saline-treated group. Diabetic mice exposed to saline exhibited higher amylase activity compared with non-diabetic mice exposed to saline. Pulmonary administration of DEP caused a significant increase in pancreatic amylase activity in diabetic mice compared with either diabetic mice exposed to saline or non-diabetic mice exposed to DEP (Fig. 5A). 


\begin{tabular}{rl|l} 
Cellular Physiology & Cell Physiol Biochem 2014;33:413-422 \\
\cline { 2 - 2 } and Biochemistry & $\begin{array}{l}\text { DOI: 10.1159/000356680 } \\
\text { Published online: February 11, 2014 }\end{array}$ & $\begin{array}{l}\text { O 2014 S. Karger AG, Basel } \\
\text { www.karger.com/cpb }\end{array}$ \\
\cline { 2 - 3 } Nemmar et al.: Diabetes and Pancreatic Effects of Diesel Particles
\end{tabular}

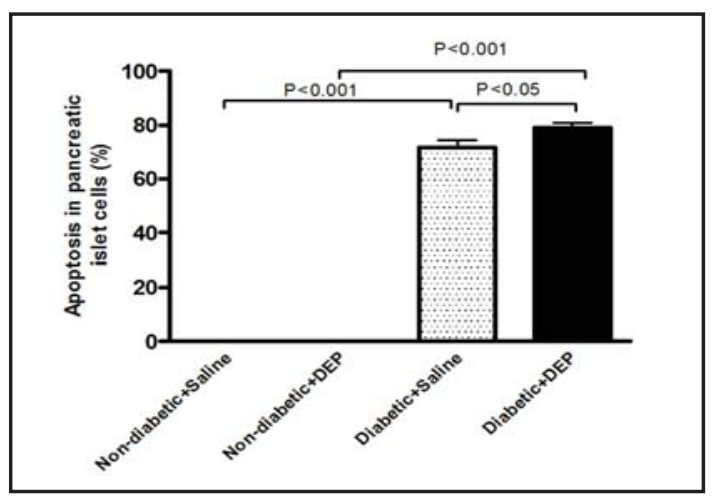

Fig. 4. Percentage apoptosis in pancreatic islet cells, $24 \mathrm{~h}$ after intratracheal instillation of either saline or diesel exhaust particles (DEP, $0.4 \mathrm{mg} / \mathrm{kg}$ ) in either non-diabetic or diabetic mice. Data are mean \pm SEM $(\mathrm{n}=6)$.

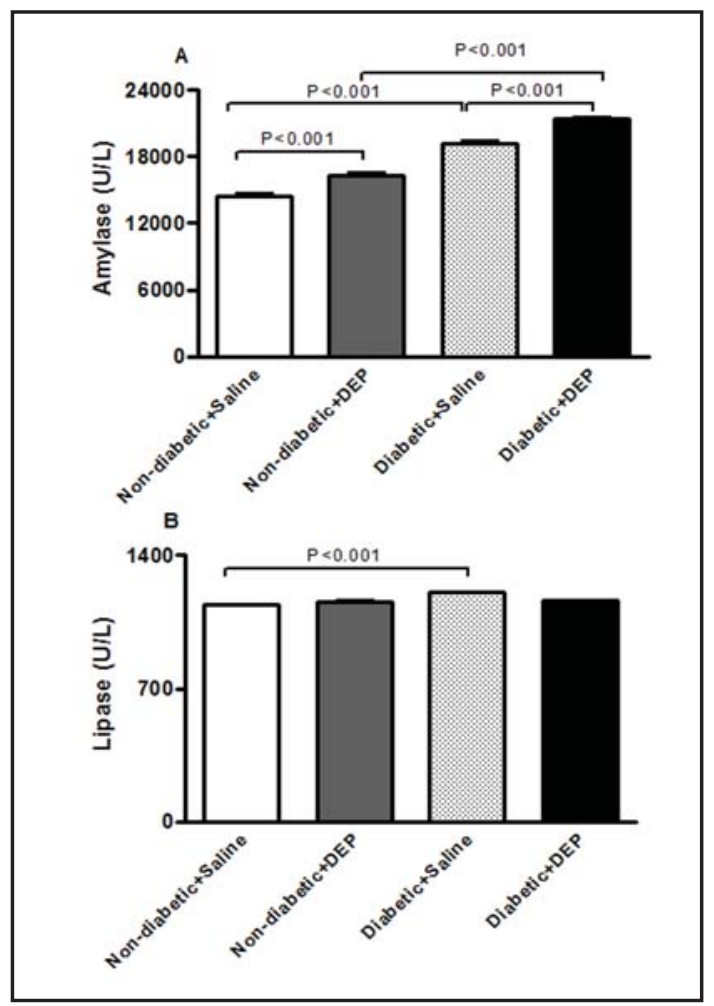

Fig. 5. Amylase (A) and lipase (B) activity in pancreatic tissue $24 \mathrm{~h}$ after intratracheal instillation of either saline or diesel exhaust particles (DEP, 0.4 $\mathrm{mg} / \mathrm{kg}$ ) in either non-diabetic or diabetic mice. Data are mean \pm SEM $(n=6)$. Error bars in figure $5 B$ are very small that is why they do not appear.

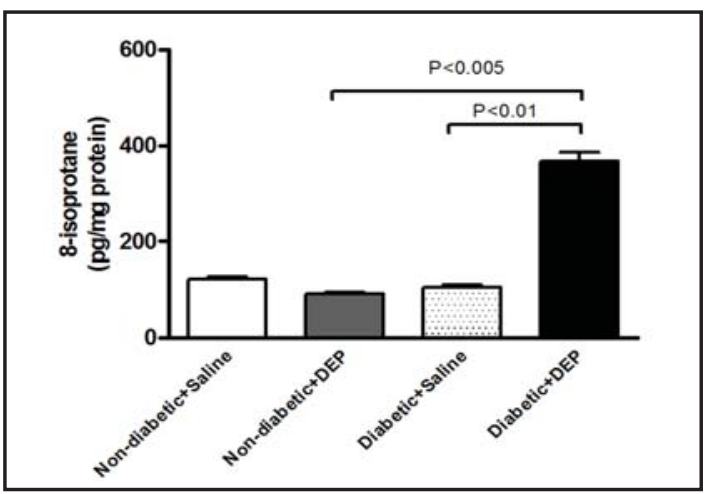

Fig. 6. 8-Isoprostane concentration in pancreatic tissue, $24 \mathrm{~h}$ after intratracheal instillation of either saline or diesel exhaust particles (DEP, $0.4 \mathrm{mg} / \mathrm{kg}$ ) in either non-diabetic or diabetic mice. Data are mean $\pm \operatorname{SEM}(n=6)$.

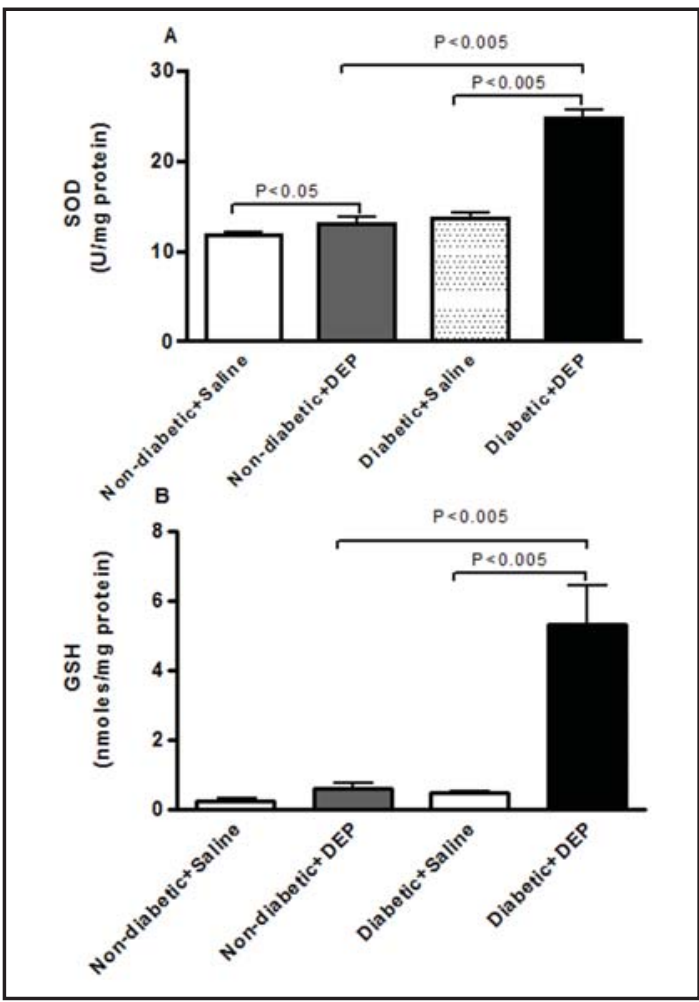

Fig. 7. Superoxide dismutase activity (SOD, A) and reduced glutathione concentration (GSH, B) in pancreatic tissue, $24 \mathrm{~h}$ after intratracheal instillation of either saline or diesel exhaust particles (DEP, 0.4 $\mathrm{mg} / \mathrm{kg}$ ) in either non-diabetic or diabetic mice. Data are mean $\pm \operatorname{SEM}(n=6)$.

The activity of pancreatic lipase was significantly increased in diabetic mice exposed to saline compared with non-diabetic exposed to saline. However, DEP exposure did not affect the activity of pancreatic lipase in either diabetic or non-diabetic mice (Fig. 5B). 


\section{Cellular Physiology and Biochemistry}

Cell Physiol Biochem 2014;33:413-422

DOI: $10.1159 / 000356680$

Published online: February 11, 2014

Fig. 8. Expression of inducible nitric oxide (iNOS) in pancreatic tissue, $24 \mathrm{~h}$ after intratracheal instillation of either saline or diesel exhaust particles $(0.4 \mathrm{mg} / \mathrm{kg})$ in either non-diabetic or diabetic mice. A: the saline-treated non-diabetic group shows no staining for iNOS in pancreatic islets cells and acini. There is mild cytoplasmic staining for iNOS in endothelial cells (arrow) using the streptavidin-biotin immunoperoxidase method. B: the DEP-treated non-diabetic group shows no staining for iNOS in pancreatic islets cells and acini. There is mild cytoplasmic staining for iNOS in endothelial cells (arrow) using the streptavidinbiotin immunoperoxidase method. C and D: the saline-treated diabetic group shows staining for iNOS in some pancreatic islet cells (arrows) using the streptavidin-biotin immunoperoxidase method. $\mathrm{E}$ and F: the DEP-treated diabetic group shows staining for iNOS in most pancreatic islet cells (thin arrows), and pancreatic acini (arrow head) using the streptavidin-biotin immunoperoxidase method.

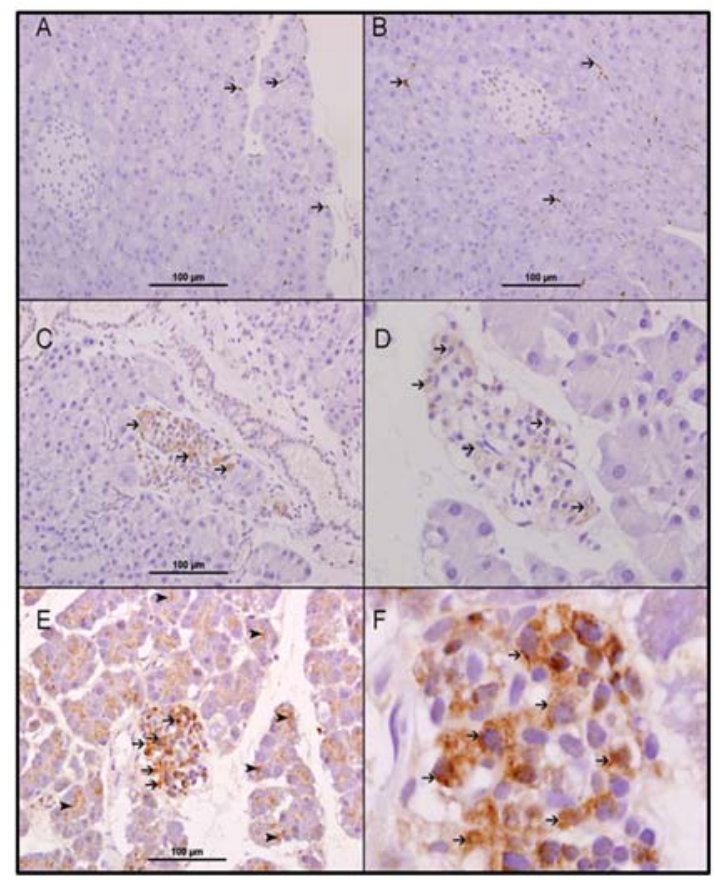

Effect of DEP on pancreatic markers of oxidative stress in diabetic and non-diabetic mice

In non-diabetic mice, DEP exposure did not affect the concentration of 8-isoprostane compared with the saline-treated group. In diabetic mice, DEP caused a significant increase in the concentrations of 8-isoprostane compared with either diabetic mice exposed to saline or non-diabetic mice exposed to DEP (Fig. 6).

Figure 7A illustrates that, in the non-diabetic group, DEP exposure induced a slight but significant increase in SOD activity compared with the saline-treated group. Interestingly, in diabetic mice, DEP caused a significant increase in SOD activity compared with either the diabetic mice exposed to saline or non-diabetic mice exposed to DEP (Fig. 7A).

Similarly, in diabetic mice, DEP caused a significant increase in the concentrations of reduced GSH compared to either diabetic mice exposed to saline or non-diabetic mice exposed to DEP (Fig. 7B).

Effect of DEP on pancreatic staining for iNOS in diabetic and non-diabetic mice

Staining for inducible nitric oxide synthase (iNOS) in non-diabetic mice exposed to either saline (Fig. 8A) or DEP (Fig. 8B) showed only mild cytoplasmic staining for iNOS in endothelial cells, and no staining in either pancreatic islets cells or acini.

In saline-treated diabetic mice, a mild cytoplasmic staining for iNOS in some pancreatic islet cells was observed (Fig. 8C-D).

In diabetic mice exposed to DEP, a marked cytoplasmic staining for iNOS in most pancreatic islet cells and some acinar cells was seen (Fig. 8 E-F).

\section{Discussion}

In the present study, we showed an aggravating effect on the pancreas of diabetic mice exposed to DEP compared with non-diabetic ones. We observed a marked decrease in the size and number of islet cells with cellular vacuolation along with a significant increase of apoptotic islet cells in diabetic mice exposed to DEP compared with those exposed to saline. Moreover, DEP caused a significant increase in pancreatic amylase activity and markers of oxidative stress including 8-isoprostane, superoxide dismutase and reduced glutathione in 


\section{Cellular Physiology and Biochemistry}

Cell Physiol Biochem 2014;33:413-422

\begin{tabular}{l|l}
\hline DOI: $10.1159 / 000356680$ & (C) 2014 S. Karger AG, Basel
\end{tabular}

diabetic mice compared with either diabetic mice exposed to saline or non-diabetic mice exposed to DEP. A more marked cytoplasmic staining for iNOS in most pancreatic islet cells and some acinar cells was seen in diabetic mice exposed to DEP compared with the salinetreated diabetic group.

It is well-established that the effects of particulate air pollution are not only limited to the lung but they can affect distant organs including heart, brain and kidney [2, 3,22]. There are three primary hypotheses which are being investigated to explain the extrapulmonary effect of nanoparticles [3]. The first one relates to the effect of particles on their ability to impact the autonomic nervous system. Inhaled particles may affect the extrapulmonary sites through inflammatory mediators produced in the lungs and released into the circulation $[2,3,22]$. Moreover, several studies have showed that nanoparticles, owing to their small size, could avoid normal phagocytic defenses in the respiratory system and gain access to the systemic circulation and, therefore reach different extrapulmonary sites [23-25]. While several studies have investigated the effects of pollutant particles on distant organs such as heart, brain and kidney $[1,3,25,26]$, so far, no study has, as far as we are aware, investigated the effect of particles on the pancreas.

We have recently assessed the respiratory and cardiovascular effects of DEP in the mouse model of type 1 diabetes, and found an aggravation of the respiratory and cardiovascular effects. Here, we continued to use the same animal model of diabetes, the dose of DEP $(0.4$ $\mathrm{mg} / \mathrm{kg}$ ) and time point (24 h post-DEP exposure) [12, 13], and assessed the pancreatic impact of these particles by assessing histological and biochemical endpoints.

Our data show that in saline-treated diabetic mice, islet cells showed cellular vacuolation and irregularity in morphology and the presence of apoptotic islet cells in the examined sections. These effects were aggravated following the exposure to DEP where islet cells displayed a marked decrease in size and number with cellular vacuolation and a significant increase in the number of apoptotic islet cells. We have recently demonstrated the presence of many apoptotic cells in the examined lung sections obtained from diabetic mice exposed to DEP [12].

In this work a significant increase in pancreatic amylase activity in non-diabetic mice exposed to DEP compared with saline ones was found. Interestingly, we also found a significant increase in pancreatic amylase activity in diabetic mice exposed to DEP compared with either diabetic mice exposed to saline or non-diabetic mice exposed to DEP. This finding suggests that DEP interact either directly $[23,24]$ or indirectly through the induction of systemic inflammation [13], with pancreatic acinar cells and cause the increase of pancreatic secretion of amylase. We have recently demonstrated that DEP cause systemic inflammation and oxidative stress in diabetic mice [13]. However, the lack of effect of DEP on pancreatic lipase activity cannot be readily explained. Additional experiments are required to clarify this point.

To assess the mechanism underlying the pancreatic effects of DEP in diabetic mice, we have measured the pancreatic concentrations of 8-isoprostane and reduced GSH and the activity of SOD. Oxidative damage to lipids (lipid peroxidation) leads to the production of isoprostanes. Isoprostanes, of which 8-isoprostane is the best-characterized isomer, are produced independently of the cyclooxygenase enzyme by the peroxidation of arachidonic acid, catalyzed by free radicals. They are considered to be a reliable index of in vivo oxidative stress because they are structurally stable and are produced in vivo $[27,28]$. Our data show that, in diabetic mice, DEP caused a significant increase in the concentrations of 8-isoprostane compared with either diabetic mice exposed to saline or non-diabetic mice exposed to DEP. We also found that the antioxidant activity of SOD and the concentrations of reduced GSH in pancreas were significantly decreased in diabetic mice exposed to DEP compared with saline-treated diabetic and DEP-treated non diabetic mice. This was possibly due to a development of oxidative stress that is accompanied by an adaptive response that counterbalances the potentially damaging activity of oxygen free radicals by antioxidant defence mechanisms. We and others have reported an increase of pulmonary antioxidants following short-term exposure to cigarette smoking $[19,29]$. 


\section{Cellular Physiology and Biochemistry}

Cell Physiol Biochem 2014;33:413-422

\begin{tabular}{l|l}
\hline DOI: $10.1159 / 000356680$ & (C) 2014 S. Karger AG, Basel
\end{tabular}

www.karger.com/cpb

Nemmar et al.: Diabetes and Pancreatic Effects of Diesel Particles

Elevated plasma markers of oxidative stress have been reported after the exposure to either DEP in mice [13] or to $\mathrm{PM}_{2.5}$ in rats [14] with type 1 diabetes.

Nitric oxide (NO), a highly reactive free radical, is produced from the amino acid L-arginine by the action of a family of isoenzymes, the nitric oxide synthases (NOS). Two broad groups can be identified: constitutive (cNOS) and iNOS [30]. Induction of iNOS produces excessive NO accompanied by increased production of reactive oxygen species, including peroxynitrite and superoxide, which are detrimental to various organs including the pancreas [31]. Our data show, in saline-exposed diabetic mice, the presence of only mild cytoplasmic staining for iNOS in some pancreatic islet cells. Importantly, in diabetic mice, following exposure to DEP, a marked cytoplasmic staining for iNOS in most pancreatic islet cells and some acinar cells was seen. This finding, along with the increase of markers of oxidative stress (8-isoprostane, reduced GSH and SOD) that we found in pancreatic homogenate, highlights the importance of oxidative stress in DEP-induced injurious pancreatic effects. iNOS overexpression was shown to be responsible for DEP-induced lung inflammation [32], while iNOS knockout mice had a significant reduction of cytokines in the lung after exposure to ambient particles [33]. iNOS expression is up-regulated by NF- $\mathrm{kB}$, which is sensitive to inflammation and oxidative stress stimulation [34]. Additional experimental studies are necessary to investigate further the mechanisms that may be underlying our observations.

In conclusion, our data showed, probably for the first time, evidence for an aggravating pancreatic effect of DEP in diabetic mice. Our findings expand the list of extrapulmonary organs that can be adversely affected by particulate air pollution to include the pancreas in a mouse model of type 1 diabetes. Epidemiological and clinical studies are needed to assess the effect of particulate air pollution on the pancreas in healthy individuals and those with pre-existing chronic diseases such as diabetes.

\section{Grants}

This work was supported by funds of the NRF-UAEU grant, and the College of Medicine and Health Sciences grant.

\section{References}

1 Gold DR, Mittleman MA: New insights into pollution and the cardiovascular system: 2010 to 2012. Circulation 2013;127:1903-1913.

- 2 Brook RD, Rajagopalan S, Pope CA, Brook JR, Bhatnagar A, Diez-Roux AV, Holguin F, Hong YL, Luepker RV, Mittleman MA, Peters A, Siscovick D, Smith SC, Whitsel L, Kaufman JD: Particulate matter air pollution and cardiovascular disease. An update to the scientific statement from the American Heart Association. Circulation 2010;121:2331-2378.

-3 Nemmar A, Holme JA, Rosas I, Schwarze PE, Alfaro-Moreno E: Recent advances in particulate matter and nanoparticle toxicology: a review of the in vivo and in vitro studies. Biomed Res Int 2013;2013:279371.

-4 Langrish JP, Bosson J, Unosson J, Muala A, Newby DE, Mills NL, Blomberg A, Sandstrom T: Cardiovascular effects of particulate air pollution exposure: time course and underlying mechanisms. J Intern Med 2012;272:224-239.

5 Dubowsky SD, Suh H, Schwartz J, Coull BA, Gold DR: Diabetes, obesity, and hypertension may enhance associations between air pollution and markers of systemic inflammation. Environ Health Perspect 2006;114:992-998.

6 O'Neill MS, Veves A, Zanobetti A, Sarnat JA, Gold DR, Economides PA, Horton ES, Schwartz J: Diabetes enhances vulnerability to particulate air pollution - Associated impairment in vascular reactivity and endothelial function. Circulation 2005;111:2913-2920.

7 Zanobetti A, Schwartz J: Cardiovascular damage by airborne particles: are diabetics more susceptible? Epidemiology 2002;13:588-592.

8 Bhatnagar A: Could dirty air cause diabetes? Circulation 2009;119:492-494.

-9 Jacobs L, Emmerechts J, Mathieu C, Hoylaerts MF, Fierens F, Hoet PH, Nemery B, Nawrot TS: Air pollution related prothrombotic changes in persons with diabetes. Environ Health Perspect 2010;118:191-196.

10 Sun Q Yue P, Deiuliis JA, Lumeng CN, Kampfrath T, Mikolaj MB, Cai Y, Ostrowski MC, Lu B, Parthasarathy S, Brook RD, Moffatt-Bruce SD, Chen LC, Rajagopalan S: Ambient air pollution exaggerates adipose inflammation and insulin resistance in a mouse model of diet-induced obesity. Circulation 2009;119:538-546. 


\section{Cellular Physiology and Biochemistry}

Cell Physiol Biochem 2014;33:413-422

DOI: $10.1159 / 000356680$

Published online: February 11, 2014

C) 2014 S. Karger AG, Basel

www.karger.com/cpb

Nemmar et al.: Diabetes and Pancreatic Effects of Diesel Particles

11 Xu X, Liu C, Xu Z, Tzan K, Zhong M, Wang A, Lippmann M, Chen LC, Rajagopalan S, Sun Q: Long-term exposure to ambient fine particulate pollution induces insulin resistance and mitochondrial alteration in adipose tissue. Toxicol Sci 2011;124:88-98.

12 Nemmar A, Al-Salam S, Subramaniyan D, Yasin J, Yuvaraju P, Beegam S, Ali BH: Influence of experimental type 1 diabetes on the pulmonary effects of diesel exhaust particles in mice. Toxicol Lett 2013; 217:170176.

-13 Nemmar A, Subramaniyan D, Yasin J, Ali BH: Impact of experimental type 1 diabetes mellitus on systemic and coagulation vulnerability in mice acutely exposed to diesel exhaust particles. Part Fibre Toxicol 2013;10:14

14 Lei YC, Hwang JS, Chan CC, Lee CT, Cheng TJ: Enhanced oxidative stress and endothelial dysfunction in streptozotocin-diabetic rats exposed to fine particles. Environ Res 2005;99:335-343.

15 Nemmar A, Al Maskari S, Ali BH, Al Amri IS: Cardiovascular and lung inflammatory effects induced by systemically administered diesel exhaust particles in rats. Am J Physiol Lung Cell Mol Physiol 2007;292:L664-L670.

16 Nemmar A, Zia S, Subramaniyan D, Al-Amri I, Al Kindi MA, Ali BH: Interaction of diesel exhaust particles with human, rat and mouse erythrocytes in vitro. Cell Physiol Biochem 2012;29:163-170.

17 Shiomi T, Tsutsui H, Ikeuchi M, Matsusaka H, Hayashidani S, Suematsu N, Wen J, Kubota T, Takeshita A: Streptozotocin-induced hyperglycemia exacerbates left ventricular remodeling and failure after experimental myocardial infarction. J Am Coll Cardiol 2003;42:165-172.

18 Denroche HC, Levi J, Wideman RD, Sequeira RM, Huynh FK, Covey SD, Kieffer TJ: Leptin therapy reverses hyperglycemia in mice with streptozotocin-induced diabetes, independent of hepatic leptin signaling. Diabetes 2011;60:1414-1423.

19 Nemmar A, Raza H, Subramaniyan D, John A, Elwasila M, Ali BH, Adeghate E: Evaluation of the pulmonary effects of short-term nose-only cigarette smoke exposure in mice. Exp Biol Med (Maywood) 2012;237:1449-1456.

20 Nemmar A, Raza H, Subramaniyan D, Yasin J, John A, Ali BH, Kazzam EE: Short-term systemic effects of nose-only cigarette smoke exposure in mice: Role of oxidative stress. Cell Physiol Biochem 2013;31:15-24.

-21 Vielhauer V, Stavrakis G, Mayadas TN: Renal cell-expressed TNF receptor 2, not receptor 1, is essential for the development of glomerulonephritis. J Clin Invest 2005;115:1199-1209.

22 Nemmar A, Hoylaerts MF, Hoet PH, Nemery B: Possible mechanisms of the cardiovascular effects of inhaled particles: systemic translocation and prothrombotic effects. Toxicol Lett 2004;149:243-253.

23 Nemmar A, Hoet PH, Vanquickenborne B, Dinsdale D, Thomeer M, Hoylaerts MF, Vanbilloen H, Mortelmans L, Nemery B: Passage of inhaled particles into the blood circulation in humans. Circulation 2002;105:411414.

24 Pery AR, Brochot C, Hoet PH, Nemmar A, Bois FY: Development of a physiologically based kinetic model for 99m-Technetium-labelled carbon nanoparticles inhaled by humans. Inhal Toxicol 2009;21:1099-1107.

25 Elder A, Gelein R, Silva V, Feikert T, Opanashuk L, Carter J, Potter R, Maynard A, Ito Y, Finkelstein J, Oberdorster G: Translocation of inhaled ultrafine manganese oxide particles to the central nervous system. Environ Health Perspect 2006;114:1172-1178.

-26 Nemmar A, Al Salam S, Zia S, Yasin J, Al H, I, Ali BH: Diesel exhaust particles in the lung aggravate experimental acute renal failure. Toxicol Sci 2010;113:267-277.

27 Birben E, Sahiner UM, Sackesen C, Erzurum S, Kalayci O: Oxidative stress and antioxidant defense. World Allergy Organ J 2012;5:9-19.

-28 Yao H, Rahman I: Current concepts on oxidative/carbonyl stress, inflammation and epigenetics in pathogenesis of chronic obstructive pulmonary disease. Toxicol Appl Pharmacol 2011;254:72-85.

29 Valenca SS, Silva BF, Lopes AA, Romana-Souza B, Marinho Cavalcante MC, Lima AB, Goncalves K, V, Porto LC: Oxidative stress in mouse plasma and lungs induced by cigarette smoke and lipopolysaccharide. Environ Res 2008;108:199-204.

-30 Rahman I, Biswas SK, Kode A: Oxidant and antioxidant balance in the airways and airway diseases. Eur J Pharmacol 2006;533:222-239.

-31 al-Mufti RA, Williamson RC, Mathie RT: Increased nitric oxide activity in a rat model of acute pancreatitis. Gut 1998;43:564-570.

32 Ito T, Ikeda M, Yamasaki H, Sagai M, Tomita T: Peroxynitrite formation by diesel exhaust particles in alveolar cells: Links to pulmonary inflammation. Environ Toxicol Pharmacol 2000;9:1-8.

-33 Becher R, Bucht A, Ovrevik J, Hongslo JK, Dahlman HJ, Samuelsen JT, Schwarze PE: Involvement of NADPH oxidase and iNOS in rodent pulmonary cytokine responses to urban air and mineral particles. Inhal Toxicol 2007;19:645-655.

34 Nathan C, Xie QW: Regulation of biosynthesis of nitric oxide. J Biol Chem 1994;269:13725-13728. 